\title{
Phytochemical Screening of Selected Botanicals and their Effectiveness Against Maize Weevil (Sitophilus Zeamais Motsch.) at Paklihawa, Rupandehi, Nepal
}

\author{
Susmita Gautam $^{1 *}$, Subodh Khanal ${ }^{1}$, Dipak Khanal ${ }^{2}$, Saroj Raj Mishra ${ }^{1}$, Sunil Ghimire ${ }^{3}$ \\ ${ }^{1}$ Department of Agri-botany and Ecology, Institute of Agriculture and Animal Science, \\ Tribhuwan University, Nepal \\ ${ }^{2}$ Department of Entomology, Institute of Agriculture and Animal Science, Tribhuwan University, Nepal \\ ${ }^{3}$ Department of Soil Science and Agri-engineering, Agriculture and Forestry University, Nepal
}

* Corresponding Author email: gautamsusmita21@gmail.com

Article Histary

Received: 29 June 2021

Revised: 01 November 2021

Accepted: 12 November 2021

Published: 23 December 2021

\section{Student(s)}

- Susmita Gautam

- Sunil Ghimire

Academic Year: 2020-2021

Course Level: Master

Course Name: Msc. Ag.

Course year: Final Year

Mentar(s)

- Subodh Khanal

- Dipak Khanal

- $\quad$ Saroj Raj Mishra

\section{ABSTRACT}

Laboratory experiment was done to perform the phytochemical screening of six locally available botanicals (Azadirachta indica Juss, Artemisia dubia Wall, Lantana camara L, Parthenium bysterophorus L, Justicia adhatoda Linn. and Moringa oleifera L.) and their effectiveness to control the maize weevil (Sitophilus zeamais Motsch.) at Agriecology lab of Institute of Agriculture and Animal Science, Paklihawa Campus, Rupandehi, Nepal. Seven treatments (leaf extract of $A$. indica, A. dubia, L. camara, P. hysterophorus. J. adhatoda and $M$. oleifera and distilled water as control) applied at 3 different doses $(0.5,1$ $\& 2 \mathrm{~g} / 50 \mathrm{~g}$ seeds) were arranged in CRD design with 3 replications. Result of mortality test of maize weevil revealed that, at highest concentration of L. camara powder (T17- $2 \mathrm{~g} / 50 \mathrm{gm}$ seeds) mortality of maize weevil was observed up to $85 \%$ at 45 DAT. Whereas number of damaged grain was lowest in T17 (L. camara powder- $2 \mathrm{~g} / 50 \mathrm{gm}$ seeds). The effectiveness of botanicals was found to increase with increasing the concentration. Besides that, Justicia adhatoda ( $2 \mathrm{~g} / 50 \mathrm{~g}$ seeds) and Artemisia dubia (1 $\mathrm{g} / 50 \mathrm{~g}$ seeds) were also found as good candidates to use for the control of Sitophilus zeamais. Qualitative tests done for the presence of various phytochemicals showed that Aradirachta indica Juss and Artemisia dubia Wall. were found to contain most of the tested metabolites among all botanicals. Most of those phytochemicals were extracted by the aqueous solution rather than other 3 menstrums used (acetone, methanol and petroleum ether). Similarly, quantitative test revealed that percentage of alkaloid was found $18.01 \%$, $17.78 \%, 17.75 \%, 11.58 \%, 8.20 \%, 6.78 \%$ and flavonoid $15.32 \%, 13.63 \%$, $12.86 \%, 11.36 \%, 7.51 \% 2.85 \%$ respectively in L. camara L. P. bysterophorus L., J. adhatoda Linn., M. oleifera L., A. indica Juss. and A. dubia Wall. Leaf extract of $L$. camera found to contain highest percentage of alkaloid $(18.01 \%)$ as well as flavonoid $(15.32 \%)$. So, it was concluded that locally available botanicals extract reach in alkaloid and flavonoid may have insecticidal property and could be use as grain protectant against the maize weevil in cost effective and eco-friendly manner.

However, application at proper dose is necessary to maintain the efficacy at higher level.

Keywords: Phytochemicals, Botanicals, Mortality, Maize weevil. 


\section{Introduction}

Maize (Zea mays) is a second staple food crop of Nepal after rice. It had a production of 2.71 million ton and area of 0.96 million having average productivity of 2.84 ton/hac [1]. Major maize growing area lies in hilly region of the country. Many small holder maize producing farmers live in remote and inaccessible area having poor road network, so difficult to dispose their production to the market. Farmers therefore have to store their product for long time, up to 6-8 month. Lots of pest attack this crop which strive with farmer and causes greater yield losses on field as well as storage conditions. At storage condition maize weevil (Sitophilus zeamais Motsch.) is one of the major insects causing heavy losses \& reduces the quality of grain [2]. It was evident that during storage condition maize weevil can causes losses of greater than $80 \%$ unprotected maize in 6 months [3]. Adult bore a hole on grain for feeding and lay egg on grain, from which larva emerge \&become more voracious until they reach maturity [4]. This ultimately leads to serious food insecurity in the country. High grain moisture conditions $(>12 \%)$, relative humidity $(>70 \%)$ and temperature conditions $\left(>27^{\circ} \mathrm{C}\right.$.) favors the growth and development of weevil thus more chance of damage [5]. Many farmers have been using various plant materials found at their locality to control the weevil but the study about their effectiveness is still lacking. Phytochemicals are the chemical extract of plant (Phyto means 'plant' in Greek) which is thought to be responsible for protective health benefits [6]. Various natural phytochemical occurs in medicinal plants, leaves, grains, vegetables, roots etc. Primary phytochemicals include chlorophyll, proteins and sugars whereas in secondary compounds flavonoid, alkaloids, sterols, terpenoids, flavonoid, saponins, tannins, volatile oils, etc [7]. Various botanicals, having secondary metabolites like flavonoid, volatiles oil, tannins, saponin, glycosides, alkaloids and resins are known to have responsible for protecting plants against pests [8]. Those plants act as inhibitors, toxicant, repellent and antifeedants against insect pest [9]. About 1,079 plants species have been described as botanical pesticide and 866 species of them possess toxicities, repellencies, physiological and deterrent effects against insects [10]. Traditionally the farmers have been using Celphos (Alumunium Phosphide) and other hazardous pesticide for the control of maize weevil but indiscriminate use of synthetic pesticides has been creating the serious health issue, environmental problems as well as insect resurgence and secondary pest outbreaks. [3, 11]. Thus, the study of best alternative from locally available botanicals is realized to reduce the losses during storage as well as various health and environmental problems. Plants like Azadiracbta india, Moringa oleifera, Nicotiana tabacum, Lantana camera, Justicia adhatoda and have been found effective to control maize weevil $[12,13]$. In this regard, study aims to explore the various phytochemicals present in six locally available botanicals (Azadirachta indica Juss, Artemisia dubia Wall, Lantana camara L, Parthenium hysterophorus L, Justicia adhatoda Linn. and Moringa oleifera L.) \& their effectiveness against the control of maize weevil at storage conditions to provide accessible, safe, reliable and inexpensive sources of control of various insect pests.

\section{Materials and Methods}

Experiment was conducted at the Agriecology lab of Institute of Agriculture and Animal Science (IAAS) Paklihawa; Rupandehi district located at $27^{\circ} 30^{\prime} \mathrm{N} 83^{\circ} 27^{\prime} \mathrm{E}$.

\subsection{Collection and Preparation of Botanicals}

Leaves \& young twigs of 6 different botanicals (Azadirachta indica Juss., Artemisia dubia Wall., Lantana camera L., Parthenium hysterophorus L. Justicia adhatoda Linn. Moringa oleifera L.) were collected as sample botanicals from Rupandehi district. Collected samples were cleaned thoroughly \& shade dried for 12 days at room temperature $\left(30 \pm 5^{\circ} \mathrm{C}\right)$. Well dried samples were made fine powder by using electrical mixture and stored in air tight plastic container for future use. 


\subsection{Preparation of Stock Solution and Screening of Phytochemicals}

For the screening of phytochemicals, stock solution was prepared by taking 50 gram of crude power of each collected sample (A. indica, A. dubia, P. hysterophorus, J adhatoda, M. oleifera L. camera) soaked in $250 \mathrm{ml}$ of 4 extraction solvent (acetone, methanol, petroleum ether, distilled water) separately and left for overnight in air tight plastic bottle for maceration. Mixture was filtered in Whatman filter paper No. 42, boiled for 5 minutes and allowed for cooling. Stock solution was made by diluting the $10 \mathrm{ml}$ prepared solution with 100 $\mathrm{ml}$ water. Prepared solution was kept is refrigerator for future use. Qualitative phytochemical screening was done for the alkaloid, flavonoid, phenol, terpenoids, and saponin by the various tests as described by [14]. Similarly quantitative determination of Alkaloid \& Flavonoid was done by gravimetric method by following procedure [15].

\subsubsection{Alkaloid Test}

$5 \mathrm{gm}$ of sample dust was dissolved in $100 \mathrm{ml}$ of $10 \%$ acetic acid solution, well shaken and left for 4 hours. The solution was then filtered in Whattman No. 42 filter paper. Filtrate was evaporated to $1 / 4^{\text {th }}$ of its original volume using hot plate with magnetic stirrer and concentrated Ammonium hydroxide $\left(\mathrm{NH}_{4} \mathrm{OH}\right)$ was added drop wise to precipitate the alkaloid content. Solution was filtered again \& washed with $1 \%$ $\mathrm{NH}_{4} \mathrm{OH}$. Filter paper containing precipitate was dried in oven at $60{ }^{\circ} \mathrm{C}$ for 30 minute \& weighted after allowed to cool for few minutes in dessicator. Weight of alkaloid was determined by using following formula

Alkaloid $\%=\mathrm{W} 2-\mathrm{W} 1 / \mathrm{W} 1 \times 100$

Where, W1 = Weight of empty filter paper

W2 $=$ Weight of paper + alkaloid precipitate

\subsubsection{Flavonoid Test}

$5 \mathrm{gm}$ of sample dust was placed in conical flask with $100 \mathrm{ml}$ of water \& $2 \mathrm{ml}$ Hydrochloric acid (HCL) solution then boiled for 30 minute\& allowed to cool before filtered in to Whattman No. 42 filter paper. Aqueous layer was discarded \& filtered with pre weighted filter paper. Residue of filter paper was dried in an oven for 30 minutes at $60{ }^{\circ} \mathrm{C}$. Weight of flavonoid was calculated by using following formula.

Flavonoid \%= W2-W1/weight of sample * 100. [15]

Where, W1 = weight of empty filter paper

W2= weight of paper + flavonoid precipitate.

\subsection{Collection and Mass Rearing of Weevil}

Initial stock of maize weevils was collected from local farmers of Paklihawa, Rupandehi district. Initial stock was transferred to plastic container having 500 gram of local variety of maize and left for mass rearing to get the large quantity of uniform aged weevils. Rearing was done in entomology lab of Institute of Agriculture and Animal Science Paklihawa campus at $28 \pm 5^{\circ} \mathrm{C}$ temperature and $80 \pm 5 \% \mathrm{RH}$ for 25 days. Second generation weevils thus obtained was used for the experiment.

\subsection{Experimental Setup to Test the Mortality of Maize Weevil (Sitophilus zeamais Motsch.)}

Before the experimental setup seeds were thoroughly examined for the presence of insect pest infections or physically damaged seeds \& such seed were discarded and dried in sunlight for 2 days to reduce the moisture content of the seed to $12 \%$ and to make seed free from insect's egg \& larva.

$50 \mathrm{gm}$ seeds were kept in plastic bottle of $250 \mathrm{ml}$ and leaf dust of each botanical was mixed thoroughly with seeds. Five pairs of maize weevil of about $12 \pm 5$ days were transferred in to each bottle covered with perforated lid. Seven treatments (leaf powder of $A$. indica, A. dubia, L. camara, P. hysterophorus. J. adhatoda, $M$. oleifera and untreated seeds as control) were maintained in 3 different doses $(0.5,1 \& 2$ gram dust in 50 gram seed). All the treatments were replicated thrice \& arranged in CRD design. 


\subsection{Data Collection}

Data of mortality of weevil was recorded by counting the number of weevil which do not respond to the pin probe and dead weevil were removed from the sample in each reading, similarly numbers of damaged grain was counted by visual examination of number of seed having exit holes made by the weevil at oneweek interval up to 45 days. Weight loss of grain was also recorded by taking weight of grain at the time of experimental set up and final reading. Weather parameters such as temperature and humidity of the room, was also recorded.

\subsection{Statistical analysis}

Data entry was done in Microsoft office excel 2007 and analyzed by using R Studio version 1.1.456. Data were subjected to analysis of variance (ANOVA) and means were separated by unprotected Least Significance Difference (LSD) at 0.05 level of significance. Data were normalized by square root transformation before analysis.

\section{Results and Discussions}

\subsection{Results of Qualitative Phytochemical Screening of Botanicals}

Table 1: Qualitative phytochemical screening of A. Indica Juss.

\begin{tabular}{|c|c|c|c|c|c|c|}
\hline S. N & Test name & DW & PE & Acetone & Methanol & Change \\
\hline \multirow[t]{3}{*}{1} & Alkaloid test & & & & & \\
\hline & Mayer's test & - & - & - & - & Green ppt \\
\hline & Wagners reagent & - & - & - & - & $\begin{array}{l}\text { Brick color } \\
\text { ppt }\end{array}$ \\
\hline \multirow[t]{3}{*}{2} & Flavonoid test & & & & & \\
\hline & Shindo's test & - & - & - & - & Pink ppt \\
\hline & Alkaline reagent test & + & - & - & - & $\begin{array}{l}\text { Colorless } \\
\text { solution }\end{array}$ \\
\hline 3 & $\begin{array}{l}\text { Phenol test } \\
\text { Pherric chloride test }\end{array}$ & - & - & - & - & $\begin{array}{l}\text { Blue black } \\
\text { solution }\end{array}$ \\
\hline 4 & $\begin{array}{l}\text { Terpenoids test } \\
\text { Copper acetate test }\end{array}$ & + & - & - & - & Green color \\
\hline 5 & $\begin{array}{l}\text { Saponins test } \\
\text { Foam test }\end{array}$ & + & - & - & - & $\begin{array}{l}\text { Foam } \\
\text { appearance }\end{array}$ \\
\hline
\end{tabular}

Note: DW- distilled water, PE- petroleum ether, $(+)=$ presence, $(-)=$ absence, ppt-precipitate.

Result of qualitative phytochemical screening indicated that among the various metabolites tested flavonoid, terpenoids, and saponins were found to be present in A. indica extract (Table 1). All those secondary metabolites were extracted in distilled water. Previous study of phytochemical screening also showed that aqueous solution of $A$. indica contained alkaloid, flavonoid, glycoside, tannin, saponin and phenol. Among them alkaloid contained was found highest [16,17]. Another study reported that ethanolic extract of $A$. indica contained alkaloid (azadirachtin), flavonoid (sodium nimbinate), tannin (salanin), terpenoids (nimbin, nimbidin) steroid (nimbidol) and phenolics compound [18]. Similarly [19] also reported the presence of alkaloid and glycoside in aqueous extract of $A$. indica leaf. 
Phytochemical Screening of Selected Botanicals and their Effectiveness Against Maize Weevil.................

Table 2: Result of qualitative phytochemical screening of A. dubia Wall.

\begin{tabular}{|c|c|c|c|c|c|c|}
\hline S. N & Test name & DW & PE & Acetone & Methanol & Change \\
\hline \multirow[t]{3}{*}{1} & Alkaloid test & & & & & \\
\hline & Mayer's test & _ & - & - & _ & Green ppt \\
\hline & Wagners reagent & + & - & - & - & $\begin{array}{l}\text { Brick color } \\
\text { ppt }\end{array}$ \\
\hline \multirow[t]{3}{*}{2} & Flavonoid test & & & & & \\
\hline & Shindo's test & - & - & - & - & Pink ppt \\
\hline & Alkaline reagent test & - & - & - & - & $\begin{array}{l}\text { Colorless } \\
\text { solution }\end{array}$ \\
\hline \multirow[t]{2}{*}{3} & Phenol test & & & & & \\
\hline & Pheric chloride test & + & - & - & - & $\begin{array}{l}\text { Blue black } \\
\text { solution }\end{array}$ \\
\hline 4 & $\begin{array}{l}\text { Terpenoids test } \\
\text { Copper acetate test }\end{array}$ & - & - & - & + & Green color \\
\hline 5 & $\begin{array}{l}\text { Saponins test } \\
\text { Foam test }\end{array}$ & + & - & - & - & $\begin{array}{l}\text { Foam } \\
\text { appearance }\end{array}$ \\
\hline
\end{tabular}

Note: DW- distilled water, PE- petroleum ether, $(+)=$ presence, $(-)=$ absence, ppt—precipitate.

Among the various metabolites tested alkaloid, phenol and saponin were found to be extracted by distilled water medium in A. Dubia Wall. (Table2). Rest of the menstrums used in experiment couldn't extract any metabolites. Result of previous experiment also reported that hexane and methanolic extract of $A$. dubia showed the presence of phenol, flavonoid, saponin, protein and amino acid [20].

Table 3: Result of qualitative phytochemical screening of $L$. camera $L$.

\begin{tabular}{|c|c|c|c|c|c|c|}
\hline S.N. & Test name & DW & $\mathrm{PE}$ & Acetone & Methanol & Indication \\
\hline \multirow[t]{3}{*}{1} & Alkaloid test & & & & & \\
\hline & Mayer's test & - & - & - & - & Green ppt \\
\hline & Wagners reagent & + & - & - & - & Brick color ppt \\
\hline \multirow[t]{3}{*}{2} & Flavonoid test & & & & & \\
\hline & Shindo's test & - & - & - & _- & Pink ppt \\
\hline & Alkaline reagent test & - & - & - & - & Colorless solution \\
\hline \multirow[t]{2}{*}{3} & Phenol test & & & & & \\
\hline & Pheric chloride test & - & - & - & - & Blue black solution \\
\hline \multirow[t]{2}{*}{4} & Terpenoids test & & & & & \\
\hline & Copper acetate test & - & - & - & - & Green color \\
\hline \multirow[t]{2}{*}{5} & Saponins test & & & & & \\
\hline & Foam test & + & _- & _- & _ & Foam appearance \\
\hline
\end{tabular}

Note: DW-distilled water, PE-petroleum ether, $(+)=$ presence, $(-)=$ absence, ppt-precipitate 
Qualitative phytochemical screening of $L$. camera found the presence of alkaloid and saponin as shown in table 3. This corresponded with the result of [21]. In previous experiments also it was evident that phytochemicals evaluations of ethanolic extract of $L$. camera revealed the presence of alkaloid, flavonoid, phenol \& steroid [22]. The result also concluded that most of the metabolites present in L. camera were best extracted by distilled water than other men strum. Similar result was also found in another experiment where overall result of phytochemicals screening using different solvent showed the presence of important metabolites like glycoside, saponin, tannin, flavonoid, terpenoids, phenolics compound, steroid [23] but in contrary to our findings alkaloids in different plant parts were present in petroleum ether extracts. Similarly, saponin and tannin were more concentrated in ethanol extracts [23].

\subsection{Result of quantitative screening of alkaloid and flavonoid}

Table 4: Result of quantitative screening of alkaloid and flavonoid

\begin{tabular}{lll}
\hline Plants & Alkaloid $\%$ & Flavonoid $\%$ \\
\hline L. camera & $18.01^{\mathrm{a}}$ & $15.32^{\mathrm{a}}$ \\
P. hysterophorus & $17.78^{\mathrm{a}}$ & $13.63^{\mathrm{b}}$ \\
J. adhatoda & $17.7^{\mathrm{a}}$ & $12.86^{\mathrm{b}}$ \\
M. oleifera & $11.8^{\mathrm{b}}$ & $11.36^{\mathrm{c}}$ \\
A. indica & $8.20^{\mathrm{c}}$ & $7.51^{\mathrm{d}}$ \\
A. dubia & $6.78^{\mathrm{d}}$ & $2.85^{\mathrm{e}}$ \\
\hline Grand mean & 13.35 & 10.59 \\
LSD value & 1.12 & 0.84 \\
MSE ( \pm$)$ & 0.40 & 0.22 \\
CV $\%$ & 4.74 & 4.50 \\
F-value & $* * *$ & $* * *$ \\
\hline
\end{tabular}

Note: DAT $=$ CV- Coefficient of Variation, LSD- Least Significant Difference, MSE $=$ Mean Squared Error, $*=$ Significant at $5 \%$ level of significance, $* *=$ Significant at $1 \%$ level of significance, ${ }^{* * *}=$ Significant at $0.1 \%$ level of significance.

Different letter signifies the significant difference among the treatments.

L. camera contains highest percentage of alkaloid (18.01\%) as well as flavonoid (15.32\%) among all the tested botanicals (Table 4). whereas $A$. dubia was found to content least amount of both metabolites $(6.78 \%$ alkaloid \&2.85\% flavonoid). The result was quite similar to findings of [24]. Previous experiment of quantitative phytochemical screening reported that neem content $11.2 \%$ alkaloid \& $2.10 \%$ flavonoid [14]. Similarly, the alkaloid \& flavonoid content of Moringa leaf was found $5.92(\mathrm{~W} / \mathrm{W})$ and flavonoid 15.74 (W/W) [17]. There was evidence that P. hysterophorus contain 5.25\% flavonoid [25]. Variation in result may be due to the plants parts used, geographical factor, solvent used and other unseen factors. Not all phytochemicals present in all plant parts \& that \% occur in different degree based on type of extracting solvent used [26] \& [27]. 
40

Phytochemical Screening of Selected Botanicals and their Effectiveness Against Maize Weevil

3.3 Mortality Test Against Maize Weevil (Sitophilus zeamais Motsch.)

Table 5: Effect of botanicals extract on mortality of maize weevil (Sitophilus zeamais Motsch.)

\begin{tabular}{|c|c|c|c|c|}
\hline \multirow[b]{2}{*}{ Treatments } & \multicolumn{2}{|c|}{ Number of dead weevil } & \multicolumn{2}{|c|}{ Number of damaged grain } \\
\hline & 24DAT & 45DAT & 31DAT & 45DAT \\
\hline A. indica $0.5 \mathrm{~g} / 50 \mathrm{~g}$ seed (T1) & $0.66^{\mathrm{de}} \pm 0.33$ & $0.66^{\mathrm{fg}} \pm 0.33$ & $2.58^{\mathrm{ab}} \pm 0.07$ & $3.05^{\mathrm{ab}} \pm 0.11$ \\
\hline P. hysterophorus $0.5 \mathrm{~g} / 50 \mathrm{~g}$ seed (T2) & $0.33^{\mathrm{e}} \pm 0.33$ & $0.33^{\mathrm{g}} \pm 0.33$ & $2.64^{\mathrm{ab}} \pm 0.11$ & $2.94^{\mathrm{bc}} \pm 0.06$ \\
\hline M. oleifera $0.5 \mathrm{~g} / 50 \mathrm{~g}$ seed (T3) & $0.91^{\mathrm{bcde}} \pm 0.50$ & $1.00^{\mathrm{efg}} \pm 0.58$ & $2.22^{\mathrm{cd}} \pm 0.13$ & $2.70^{\mathrm{cd}} \pm 0.06$ \\
\hline A. dubia $0.5 \mathrm{~g} / 50 \mathrm{~g}$ seed (T4) & $0.33^{\mathrm{e}} \quad \pm 0.33$ & $0.80^{\mathrm{fg}} \pm 0.42$ & $2.37^{\mathrm{bc}} \pm 0.07$ & $2.51^{\mathrm{de}} \pm 0.07$ \\
\hline L. camera $0.5 \mathrm{~g} / 50 \mathrm{~g}$ seed (T5) & $1.13^{\text {abcde }} \pm 0.14$ & $1.38^{\mathrm{cdef}} \pm 0.21$ & $1.82^{\text {efgh }} \pm 0.09$ & $2.07^{\mathrm{fgh}} \pm 0.08$ \\
\hline J. adhatoda $0.5 \mathrm{~g} / 50 \mathrm{~g}$ seed (T6) & $0.80^{\mathrm{de}} \pm 0.42$ & $1.24^{\text {cdef }} \pm 0.24$ & $2.07^{\mathrm{cde}} \pm 0.08$ & $2.30^{\mathrm{ef}} \pm 0.07$ \\
\hline A. indica $1 \mathrm{~g} / 50 \mathrm{~g}$ seed (T7) & $1.57^{\mathrm{abcd}} \pm 0.30$ & $1.98^{\mathrm{bcd}} \pm 0.15$ & $2.00^{\text {def }} \pm 0.00$ & $2.29^{\mathrm{efg}} \pm 0.19$ \\
\hline P. hysterophorus $1 \mathrm{~g} / 50 \mathrm{~g}$ seed (T8) & $0.33^{\mathrm{e}} \pm 0.33$ & $1.13^{\operatorname{defg}_{ \pm}} \pm 0.14$ & $2.07^{\text {cde }} \pm 0.08$ & $2.37^{\mathrm{ef}} \pm 0.07$ \\
\hline M. oleifera $1 \mathrm{~g} / 50 \mathrm{~g} \operatorname{seed}(\mathrm{T} 9)$ & $1.33^{\text {abcde }} \pm 0.33$ & $1.79^{\text {bcde }} \pm 0.24$ & $2.15^{\mathrm{cd}} \pm 0.08$ & $2.22^{\mathrm{efg}} \pm 0.13$ \\
\hline A. dubia $1 \mathrm{~g} / 50 \mathrm{~g}$ seed (T10) & $1.90^{\mathrm{abc}} \pm 0.17$ & $2.06^{\mathrm{abc}} \pm 0.21$ & $1.91^{\mathrm{defg}} \pm 0.09$ & $2.23^{\mathrm{efg}} \pm 0.00$ \\
\hline L. camera $1 \mathrm{~g} / 50 \mathrm{~g}$ seed (T11) & $1.47^{\mathrm{abcd}} \pm 0.29$ & $1.95^{\mathrm{bcd}} \pm 0.30$ & $1.52^{\mathrm{hi}} \pm 0.11$ & $1.71^{\mathrm{i}} \pm 0.17$ \\
\hline J. adhatoda $1 \mathrm{~g} / 50 \mathrm{~g}$ seed (T12) & $1.27^{\mathrm{abcde}} \pm 0.14$ & $1.91^{\mathrm{bcd}} \pm 0.09$ & $1.98^{\mathrm{def}} \pm 0.15$ & $1.91^{\mathrm{hi}} \pm 0.09$ \\
\hline of $A$. indica $2 \mathrm{~g} / 50 \mathrm{~g}$ seed (T13) & $1.24^{\mathrm{abcde}} \pm 0.24$ & $2.07^{\mathrm{abc}} \pm 0.08$ & $1.52^{\mathrm{hi}} \pm 0.11$ & $1.90 \stackrel{\mathrm{hi}}{ \pm 0.17}$ \\
\hline P. hysterophorus 2g/50g seed (T14) & $1.13^{\mathrm{abcde}} \pm 0.59$ & $2.06^{\mathrm{abc}} \pm 0.17$ & $1.91 \stackrel{\text { defg }}{ \pm 0.09}$ & $2.00^{\text {ghi }} \pm 0.00$ \\
\hline M. oleifera 2g/50g seed(T15) & $1.13^{\mathrm{abcde}} \pm 0.59$ & $2.06^{\mathrm{abc}} \pm 27$ & $1.62^{\text {ghi }} \pm^{0.11}$ & $1.82^{\mathrm{hi}} \pm 0.09$ \\
\hline A. dubia $2 \mathrm{~g} / 50 \mathrm{~g}$ seed (T16) & $1.66^{\mathrm{abcd}} \pm 0.33$ & $2.36^{\mathrm{ab}} \pm 0.19$ & $1.71^{\text {fghi }} \pm 0.17$ & $1.71^{\mathrm{i}} \pm 0.17$ \\
\hline L. camera $2 \mathrm{~g} / 50 \mathrm{~g}$ seed (T17) & $2.07^{\mathrm{a}} \pm 0.08$ & $2.88^{\mathrm{a}} \pm 0.06$ & $1.13^{\mathrm{j}} \pm 0.14$ & $1.41^{j} \pm 0.00$ \\
\hline J. adhatoda $2 \mathrm{~g} / 50 \mathrm{~g}$ seed (T18) & $1.971^{\mathrm{ab}} \pm 0.24$ & $2.69^{\mathrm{ab}} \pm 0.16$ & $1.41^{\mathrm{ij}} \pm 0.00$ & $1.82^{\mathrm{hi}} \pm 0.09$ \\
\hline control (T19) & $0.33^{\mathrm{e}} \pm 0.33$ & $0.80{ }^{\mathrm{fg}} \pm 0.42$ & $2.76^{\mathrm{a}} \pm 0.06$ & $3.26^{\mathrm{a}} \pm 0.10$ \\
\hline Grand mean & 1.13 & 1.63 & 1.97 & 2.22 \\
\hline LSD value & 0.97 & 0.78 & 0.28 & 0.26 \\
\hline $\mathrm{CV} \%$ & 51.87 & 28.88 & 8.63 & 7.21 \\
\hline F-value & $* *$ & $* * *$ & $* * *$ & $* * *$ \\
\hline
\end{tabular}

Note: DAT $=$ Days After Treatment, CV- coefficient of variation, LSD- least significant difference, $*=$ Significant at $5 \%$ level of significance, $* *=$ Significant at $1 \%$ level of significance, $* * *=$ Significant at $0.1 \%$ level of significance.

Different letter signifies the significant difference among the treatments. 
Among all sample botanicals, L. camera leaf extract showed the highest mortality of maize weevil (Table5). Efficiency of mortality of weevil decreased with decreasing concentration of botanical extracts. Result was also corresponding with the other research findings. Among the five different locally available plants, lantana \& Neem leaf extract showed highest mortality against the maize weevil [28]. Among 2 botanicals tested against synthetic pesticides $L$. camera causes $82.7-90 \%$ mortality of maize weevil after 21 days of treatment [29]. Lowest number of damaged grain was observed in seeds treated with $L$. camera $2 \mathrm{~g} / 50 \mathrm{~g}$ seed (T17). Among 5 different plant powders, $6 \mathrm{~g}$ lantana $/ 100 \mathrm{~g}$ seed caused $7.57 \%$ reduction in grain damage compared to untreated seeds [30]. Findings of previous research also revealed that different extract of leaf powder \& extracted oil of lantana camera possessed insecticidal property against maize weevil (Sitophilus zeamais). Repellency and mortality for insect was due to the presence of different bioactive and phytochemical molecules such as Phytol, Pyrroline, paromomycin, pyrrolizin and I-Eicosano [31].

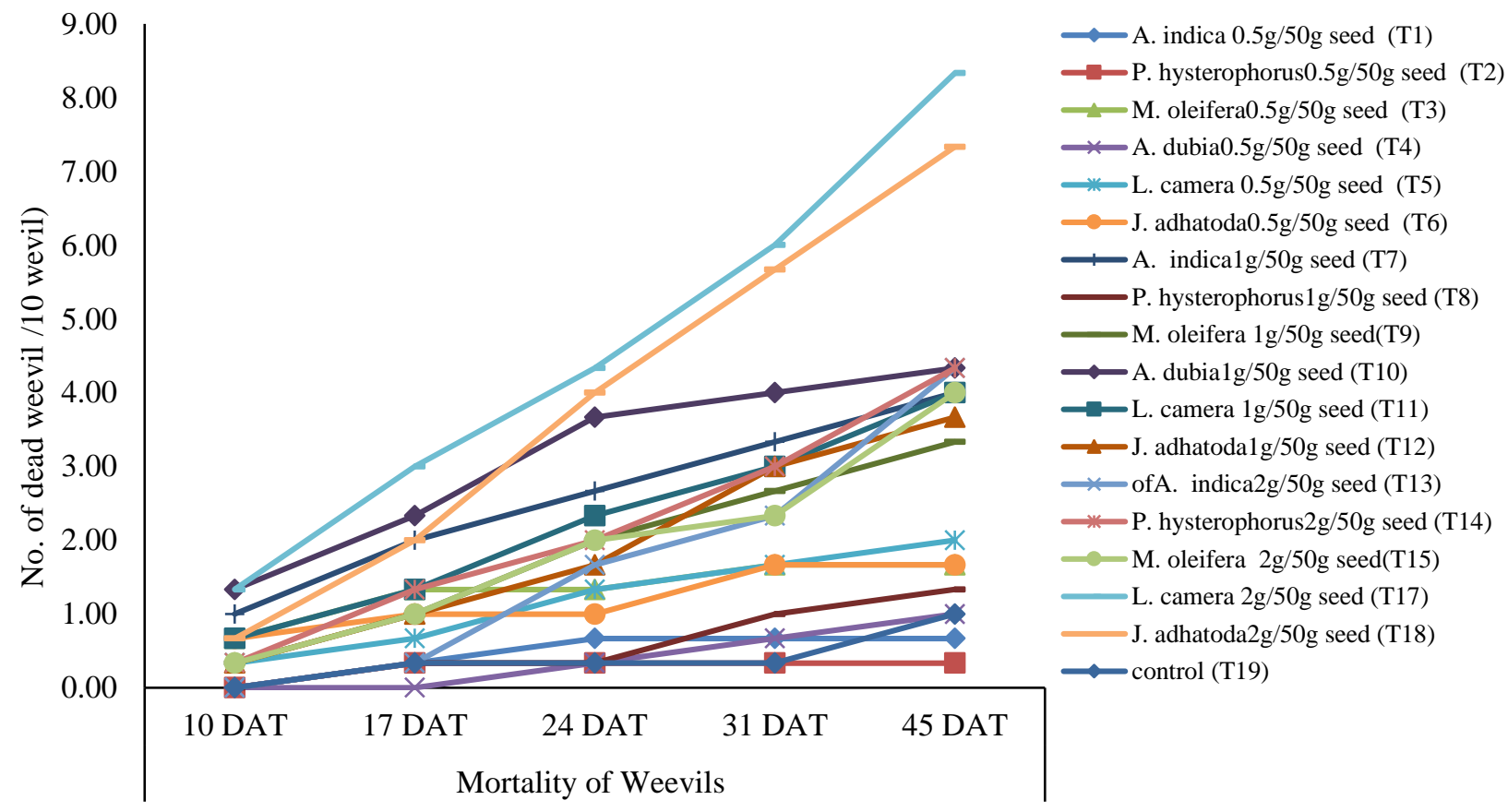

Days after Treatment Application

Figure 1: Mortality of maize weevil over time

Graph above illustrate the trend of mortality of maize weevil over entire research period. At 45 DAT the count of dead weevil was found highest at treatment 17 (2gm Lantana camera /50 gm seed) (Figure1) Out of 10 weevils kept, on an average 8.5 weevils was found dead. It meant that among the various tested botanicals 2 gm leaf dust of Lantana camera per 50 gram maize seeds resulted in $85 \%$ mortality of maize weevil at 45DAT. Result was almost similar to previous experiment which reported that among 2 botanicals tested, with synthetic pesticide L. camera causes $82.7-90 \%$ mortality of maize weevil after 21 days of treatment [28].

\section{Conclusion}

Among the five different metabolites tested saponin and amino acid was found in most botanicals. Leaf extract of Azadirachta indica and Artemisia dubia contained most of the tested metabolites compared to other botanicals tested in the experiment. Most of these metabolites were extracted by the aqueous solution rather than other 3 menstrum (acetone, methanol, and petroleum ether). Quantitative phytochemical screening 
revealed that $L$. camera contains highest percentage of alkaloid (18.01\%) as well as flavonoid $(15.32 \%)$ among all the tested botanicals. whereas $A$. dubia was found to contain least amount of both metabolites ( $6.78 \%$ alkaloid \& $2.85 \%$ flavonoid). Among the application of leaf powder of 6 locally available botanicals at 3 different doses $(0.5,1 \& 2 \mathrm{gram} / 100 \mathrm{gram}$ seeds), highest mortality of maize weevil (Sitophilus zeamais Motsch.) was recorded in leaf powder of Lantana camara $2 \mathrm{~g} / 50 \mathrm{gm}$ seeds, while the number of damaged grains was lowest.At 45 DAT Lantana camara at the dose of $2 \mathrm{~g} / 50 \mathrm{gm}$ seeds showed $85 \%$ mortality of maize weevil. The effectiveness was found decreasing at smaller doses. Besides that, Justicia adhatoda and Artemisia dubia were also found as good candidates to use for the control of one of the major pests of maize at storage conditions. Thus, these botanicals have insecticidal property and could be use as grain protectant against the maize weevil at storage condition.

\section{Declarations}

\subsection{Study Limitations}

Phytochemicals present in the botanical may differ with various solvents used, method of extraction as well as plant parts used for the study. Similarly, the efficacy of botanicals extract for the insect pest control may also vary with plants part used, form at which botanicals used and dose of extract.

\subsection{Acknowledgement}

Authors would like to acknowledge the financial support from National Youth Council (NYC) Sanothimi, Bhaktapur as well as Institute of Agriculture and Animal Science (IAAS) Paklihawa campus, Rupandehi for providing easy access to lab facility as well as other required materials for the completion of our research.

\subsection{Competing Interests}

Authors declare that there is no conflict of interest.

\section{How to Cite this Article:}

S. Gautam, S. Khanal, D. Khanal, S. R. Mishra, and S. Ghimire, "Phytochemical Screening of Selected Botanicals and their Effectiveness Against Maize Weevil (Sitophilus Zeamais Motsch.) at Paklihawa, Rupandehi, Nepal", Adv. J. Grad. Res., vol. 11, no. 1, pp. 34-44, Dec. 2021.

\section{References}

[1] MoALD, Statistical Information on Nepalese Agriculture 2018/19, Ministry of Agriculture and Livestock Development (MoALD), Kathmandu, Nepal, Aug 2020.

[2] T. F. Erenso and D. H. Berhe. "Effect of neem leaf and seed powders against adult maize weevil (Sitophilus zeamaisMotschulsky) mortality.", Int. J. Agric. Res, Vol. 11, pp. 90-94, 2016.

[3] E. N. Nukenine. "Stored product protection in Africa: Past, present and future.", Julius-Kühn-Archiv, Issue 425, pp. 26, Sept 2010. DOI: 10.5073/jka.2010.425.177

[4] L. C. Nwosu. "Impact of age on the biological activities of Sitophilus zeamais (Coleoptera: Curculionidae) adults on stored maize: implications for food security and pest management.", Journal of economic entomology, Vol. 111 Issue 5, pp. 2454-2460, Oct 2018. https://doi.org/10.1093/jee/toy187

[5] D. Khanal, S. B. Neupane, A. Bhattarai, S. Khatri-Chhetri, N. Nakarmi, S. Sapkota and V. Sharma. "Evaluation of Botanical Powders for the Management of Rice Weevil (Sitophilus oryzae L. Coleoptera: Curculionidae) in Rupandehi, Nepal.", Advances in Agriculture, Jan 2021. https://doi.org/10.1155/2021/8878525

[6] D. Webb, "Phytochemicals' role in good health.”, Today's Dietitian, Vol. 15 Issue 9, p.70, 2013.

[7] M. A. Motalab, "Selected medicinal plants of Chittagong hill tracts. IUCN Bangladesh.", 2011.

[8] S. Rajni and S. Priyam, "Study of insecticidal activity of acetone crude leaf extract of Adhatodavasica against Callosobruchus maculates.", World Journal of Pharmacy and Pharmaceutical Sciences, Vol. 3, Issue9, pp. 15731577, 2014. 
[9] A. Trivedi, N. Nayak, and J. Kumar. "Recent advances and review on use of botanicals from medicinal and aromatic plants in stored grain pest management.", Journal of Entomology and Zoology Studies, Vol. 6 Issue 3, pp. 295-300, Apr 2018.

[10] A. Prakash and J. Roa, Botanical Pesticides in Agriculture Lewis Publishers, 1997.

[11] V. D. Brito, F. Achimón, R. P. Pizzolitto, A. R. Sánchez, E. A. G. Torres, J. A. Zygadlo and M. P. Zunino. "An alternative to reduce the use of the synthetic insecticide against the maize weevil Sitophilus zeamais through the synergistic action of Pimentaracemosa and Citrus sinensis essential oils with chlorpyrifos.", Journal of Pest Science, Vol. 94, Issue 2, pp. 409-421, March 2021. https://doi.org/10.1007/s10340-020-01264-0

[12] S. Karunakaran and V. Arulnandhy. "Insecticidal activity of selected botanicals on maize weevil, Sitophilus zeamais L., in stored maize grains.", AGRIEAST: J. Agric. Sci, Vol. 12, Issue1, pp. 1-6, June 2018. DOI: http://doi.org/10.4038/agrieast.v12i1.46

[13] K. D. Ileke and M. O. Oni. "Toxicity of some plant powders to maize weevil, Sitophilus zeamais (motschulsky)[Coleoptera: Curculiondae] on stored wheat grains (Triticum aestivum).", African Journal of Agricultural Research, Vol. 6, Issue13, pp. 3043-3048, July 2011. https://doi.org/10.5897/AJAR.9000745

[14] G. Visweswari, R. Christopher, and W. Rajendra, "Phytochemical screening of active secondary metabolites present in Withaniasomnifera root: role in traditional medicine.", International journal of pharmaceutical sciences and research, Vol. 4, Issue 7, p. 2770, June 2013.

[15] J. B. Harborne, "Phenolic compounds.", In Phytochemical methods, pp. 33-88, 1973. doi: https://doi.org/10.1007/978-94-009-5921-7_2.

[16] K. C. Ugoeze, P. C. Aja, N. Nwachukwu, B. C. Chinko\& J. N. Egwurugwu. "Assessment of the phytoconstituents and optimal applicable concentration of aqueous extract of Azadirachta indica leaves for wound healing in male Wistar rats.", Thai Journal of Pharmaceutical Sciences (TJPS), Vol. 45, Issue 1, Jan 2021.

[17] K. C. Ugoeze, K. E. Oluigbo, and B. C. Chinko. "Phytomedicinal and Nutraceutical Benefits of the GC-FID Quantified Phytocomponents of the Aqueous Extract of Azadirachta indica leaves.", Journal of Pharmacy and Pharmacology Research, Vol. 4, Issue 4, pp. 149-163, Dec 2020. DOI: 10.26502/fjppr.039

[18] G. Gebremedhin, T. Tesfay, K. K. Chaithanya and K. Kamalakararao. "Phytochemical screening and in vitro antidandruff activities of bark extracts of neem (Azadirachta indica).", Drug. Invent. Today, Vol. 13, pp. 707-713, May 2020.

[19] A. Uwague, "Comparative Potential Qualitative and Quantitative Phytochemical Evaluation of Neem and Moringa Oleifera Leaf Plants in Ozoro.", pp. 120-340. Nov. - Dec. 2019. doi: https://doi.org/10.32628/IJSRST196652

[20] P. K. Ashok and K. Upadhaya, "Preliminary phytochemical screening and physico-chemical parameters of aerial parts of Artemisia vulgaris.", International Journal of Research in Ayurveda and Pharmacy (IJRAP), vol. 1, Issue 1, pp. 206-211, 2010.

[21] R. A. Sardhara and S. Gopal, "Qualitative phytochemical screening of different solvent extracts of tinosporacordifolia stem and lantana camara flower. Int. Res. J. Pharm.”, Applied Science, vol. 3, Issue 5, pp. 210-213, Oct 2013.

[22] [M. A. Etuh, L. T. Ohemu, and D. D. Pam. "Lantana camara ethanolic leaves extracts exhibit anti-aging properties in Drosophila melanogaster: survival-rate and life span studies.", Toxicology Research, Vol. 10, Issue 1, pp 79-83, Jan 2021. doi: 10.1093/toxres/tfaa098

[23] H. Gul and M. A. Sajad. "An evaluation of phytochemical screening of Lantana camara Linn. (An invasive plant species of Pakistan).", Pure and Applied Biology (PAB), Vol. 9, pp.1856-1863, Aug 2020. http://dx.doi.org/10.19045/bspab.2020.90198

[24] E. Bhuvaneswari and R. S. Giri. "Physicochemical and phytochemical screening in Lantana camara leaves.", Journal of Pharmacognosy and Phytochemistry, Vol. 7, Issue 6, pp. 1962-1966, March 2018.

[25] P. Pradhan and Y. S. Sarangdevot. "Estimation of total Phenols and flavonoids content in parthenium hysterophorus aerial parts.", Plant Archives, Vol. 20, Issue 1, pp. 988-990, 2020.

[26] B. A. Ayinde, D. N. Onwukaeme, and E.K. Omogbai, "Isolation and characterization of two phenolic compounds from the stem bark of Musangacecropioides R. Brown (Moraceae)," Acta Pol. Pharm, Vol. 64, Issue2, pp. 183-5, March 2007. doi: 10.11648/j.ijnfs.20140306.23

[27] M. B. Tijjani, I.A. Bello, A.B. Aliyu, T. Olurishe, S.M. Maidawa, J.D. Habila, and E.O. Balogun, "Phytochemical and antibacterial studies of root extract of Cochlospermumtinctorium A. Rich. (Cochlospermaceae)," Research Journal of Medicinal Plant, Vol. 3, Issue 1, pp. 16-22, 2009. doi: http://dx.doi.org/10.3923/rjmp.2009.16.22

[28] M. L. Parugrug and A.C. Roxas, "Insecticidal action of five plants against maize weevil, Sitophilus zeamais Motsch," (Coleoptera: Curculionidae). Current applied science and technology, Vol. 8, Issue 1, pp. 24-38, March 2018. 
[29] J. O. Ogendo, S. R. Belmain, A. L. Deng, and D. J. Walker, "Comparison of Toxic and Repellent Effects of Lantana camara L. with TePhrosiavogelii Hook and A Synthetic Pesticide Against Sitophiluszeamais Motschulsky (Coleoptera: Gurculionidae) in Stored Maize Grain.”, International Journal of tropical insect science, Vol. 23, Issue 2, pp. 127-135, June 2003. doi: https://doi.org/10.1017/S1742758400020348

[30] M. A. Mahmoud and O. A. A. Zedan, "Essaying some Plant Powders against Maize Weevil, Sitophiluszeamais (Motsch.), for Protecting Maize Grains from Damage.”, Journal of Plant Protection and Pathology, Vol. 9, Issue 11, pp. 729-734, Nov 2018. doi: 10.21608/jppp.2018.44041.

[31] A. A. Ayalew, "Insecticidal activity of Lantana camara extract oil on controlling maize grain weevils.", Toxicology Research and Application, 4, 2397847320906491. 2020. https://doi.org/10.1177/2397847320906491

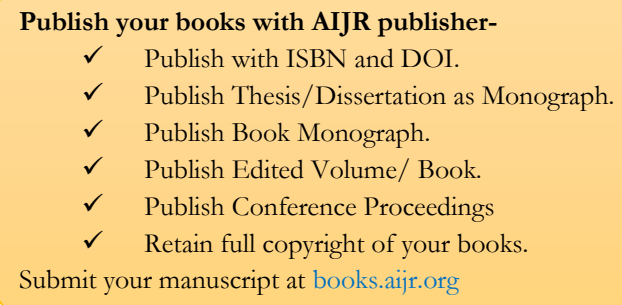

\section{Publish your research article in AIJR journals-}

$\checkmark \quad$ Online Submission and Tracking

$\checkmark \quad$ Peer-Reviewed

$\checkmark \quad$ Rapid decision

$\checkmark \quad$ Immediate Publication after acceptance

$\checkmark \quad$ Articles freely available online

$\checkmark \quad$ Retain full copyright of your article. Submit your article at journals.aijr.org 